\title{
Eukaryotic community composition in the sea surface microlayer across an east-west transect in the Mediterranean Sea
}

\author{
Birthe Zäncker $^{1,2}$, Michael Cunliffe ${ }^{2,3}$, and Anja Engel ${ }^{1}$ \\ ${ }^{1}$ GEOMAR, Helmholtz Centre for Ocean Research Kiel, 24105 Kiel, Germany \\ ${ }^{2}$ Marine Biological Association of the UK, Plymouth, PL1 2PB, UK \\ ${ }^{3}$ School of Biological and Marine Sciences, University of Plymouth, Plymouth, PL4 8AA, UK
}

Correspondence: Anja Engel (aengel@geomar.de)

Received: 29 June 2020 - Discussion started: 21 July 2020

Revised: 6 January 2021 - Accepted: 1 February 2021 - Published: 23 March 2021

\begin{abstract}
The sea surface microlayer (SML) represents the boundary layer at the air-sea interface. Microbial eukaryotes in the SML potentially influence air-sea gas exchange directly by taking up and producing gases and indirectly by excreting and degrading organic matter, which may modify the viscoelastic properties of the SML. However, little is known about the distribution of microbial eukaryotes in the SML. We studied the composition of the microbial community, transparent exopolymer particles and polysaccharides in the SML during the PEACETIME cruise along a westeast transect in the Mediterranean Sea, covering the western basin, Tyrrhenian Sea and Ionian Sea. At the stations located in the Ionian Sea, fungi - likely of continental origin and delivered by atmospheric deposition - were found in high relative abundances, making up a significant proportion of the sequences recovered. Concomitantly, bacterial and picophytoplankton counts decreased from west to east, while transparent exopolymer particle (TEP) abundance and total carbohydrate (TCHO) concentrations remained constant in all basins. Our results suggest that the presence of substrates for fungi, such as Cladosporium, known to take up phytoplankton-derived polysaccharides, in combination with decreased substrate competition by bacteria, might favor fungal dominance in the neuston of the Ionian Sea and other low-nutrient, low-chlorophyll (LNLC) regions.
\end{abstract}

\section{Introduction}

The sea surface microlayer (SML) constitutes a 1 to $100 \mu \mathrm{m}$ thick boundary layer between the ocean and the atmosphere (Cunliffe and Murrell, 2010; Liss and Duce, 2005; Zhang et al., 2003) with distinct physical and chemical properties compared to the underlying water (Cunliffe et al., 2013; Zhang et al., 2003). The SML potentially has a substantial influence on air-sea exchange processes, such as gas transfer and sea spray aerosol formation (Cunliffe et al., 2013; Engel et al., 2017; Freney et al., 2020; Sellegri et al., 2021).

The microbial food web plays a crucial role in ocean biogeochemistry and has been vastly studied. Despite the fact that microbes in the SML can directly and indirectly influence air-sea gas exchange, few studies have looked at the microbial community composition in the SML and have mainly focused on bacteria (Agogué et al., 2005; Joux et al., 2006; Obernosterer et al., 2008) with little attention to microbial eukaryotes (Taylor and Cunliffe, 2014). While phytoplankton throughout the water column play an important role in the ocean as primary producers, phytoneuston in the SML (Apts, 1989; Hardy and Apts, 1984; Naumann, 1917) might have an additional crucial role by impacting air-sea gas exchange (Ploug, 2008; Upstill-Goddard et al., 2003). Early microscopic observations of the SML reported mostly diatoms, dinoflagellates and cyanobacteria (Hardy et al., 1988). More recent studies using $18 \mathrm{~S}$ rRNA gene sequencing found a decreased protist diversity in the SML compared to underlying water with chrysophytes and diatoms enriched in the SML (Cunliffe and Murrell, 2010; Taylor and Cunliffe, 2014).

Not only phytoneuston, but also zooneuston, bacterioneuston and myconeuston might influence air-sea gas ex- 
change processes by either parasitizing phytoneuston and thus impacting the primary productivity or by degrading organic matter available in the SML and releasing $\mathrm{CO}_{2}$. While some studies have explored bacterioneuston diversity in the Mediterranean Sea (Agogué et al., 2005; Joux et al., 2006), fungi have not yet been characterized in the SML in this region. Fungi are however abundant in marine environments (Gladfelter et al., 2019; Grossart et al., 2019; Hassett et al., 2019), living a saprotrophic or parasitic lifestyle, and have been found in the Mediterranean Sea before (Garzoli et al., 2015; Gnavi et al., 2017) and in the myconeuston studied at other locations (Taylor and Cunliffe, 2014).

Phytoplankton and phytoneuston can release precursors such as carbohydrates which can aggregate and form gelatinous particles such as transparent exopolymer particles (TEPs) (Chin et al., 1998; Engel et al., 2004; Verdugo et al., 2004). TEPs contain mainly polysaccharides (Mopper et al., 1995; Passow, 2002), occur ubiquitously in the ocean (Alldredge et al., 1993; Passow, 2002) and are an important structural component of the SML (Wurl and Holmes, 2008; Cunliffe and Murrell, 2009). Due to their stickiness TEPs can aggregate with other denser particles (Azetsu-Scott and Passow, 2004; Engel, 2000; Passow and Alldredge, 1995) and eventually sink out of the euphotic layer into the deep ocean, leading to carbon export (Engel et al., 2004). However, the rate of TEP-related carbon export does not only depend on TEP production by phytoplankton, but also on their microbial degradation.

Few studies have looked at the spatial distribution of the microbial eukaryote communities in the SML and possible environmental drivers of community composition in the open Mediterranean Sea, a characteristic low-nutrient, lowchlorophyll (LNLC) region (Durrieu de Madron et al., 2011). The anti-estuarine circulations at the Strait of Gibraltar and the Strait of Sicily transport low-nutrient surface waters into the basins and deeper waters out of the basins, resulting in oligotrophic conditions and ultra-oligotrophic conditions in the western and eastern Mediterranean basin, respectively (Krom et al., 2004; Mermex Group et al., 2011; Pujo-Pay et al., 2011; Tanhua et al., 2013). The present study focuses on TEPs as important structural components of the SML and their precursors, carbohydrates, and microbial eukaryotes distribution, focusing on the myconeuston community composition in the SML using samples collected during the PEACETIME cruise in the Mediterranean Sea during May and June 2017.

\section{Material and methods}

\subsection{Sampling}

Samples were collected on board the RV Pourquoi pas? from 10 May to 11 June 2017. Water from the SML and the underlying water (ULW; $20 \mathrm{~cm}$ below the SML) was collected at

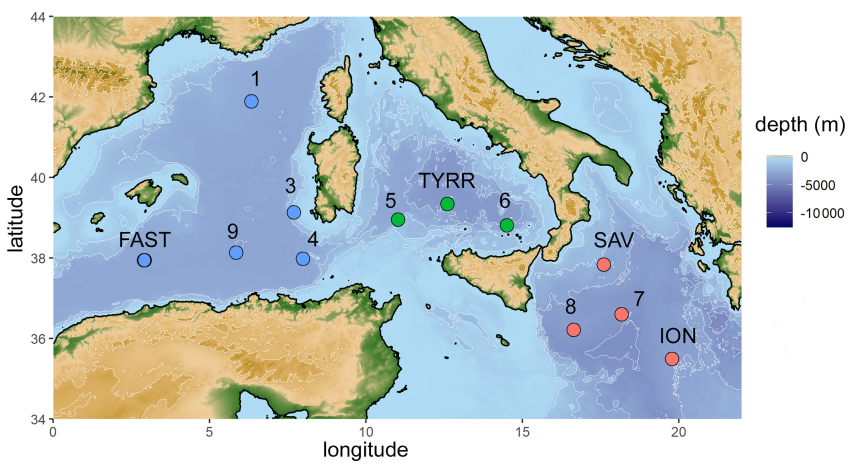

Figure 1. Map of the stations sampled during the PEACETIME cruise in the Mediterranean Sea in May/June 2017. Stations FAST and TYRR were sampled twice. Colors represent sampled basins (blue: western basin, green: Tyrrhenian Sea, red: Ionian Sea).

12 stations from 2.9 to $19.8^{\circ} \mathrm{E}$ and 35.5 to $42.0^{\circ} \mathrm{N}$ (Fig. 1). SML samples were collected from a zodiac using a glass plate sampler (Cunliffe and Wurl, 2014; Harvey, 1966). The dimensions of the silicate glass plate $(50 \times 26 \mathrm{~cm})$ resulted in an effective sampling surface area of $2600 \mathrm{~cm}^{2}$ considering both sides. To avoid contamination during sampling, the zodiac was positioned upwind and in front of the research vessel. The glass plate was immersed and withdrawn perpendicular to the sea surface. With a Teflon wiper, SML samples were collected in acid-cleaned and rinsed bottles (Cunliffe and Wurl, 2014). Approximately $1.5 \mathrm{~L}$ of SML sample was collected in the course of $1 \mathrm{~h}$. Sampling times are listed in Table 1 . All sampling equipment was acid-cleaned $(10 \% \mathrm{HCl})$, rinsed with Milli-Q and copiously rinsed with seawater from the respective depth once the sampling site was reached. The ULW samples were collected simultaneously with two acidcleaned and Milli-Q-rinsed glass bottles by immersing the closed bottles and opening them at approximately $20 \mathrm{~cm}$.

\subsection{Gel particle determination}

The abundance and area of TEP was measured microscopically (Engel, 2009). The sample volume $(10-30 \mathrm{~mL})$ was chosen according to the prevailing TEP concentrations. Samples were filtered onto $0.4 \mu \mathrm{m}$ Nuclepore membranes (Whatman) and stained with $1 \mathrm{~mL}$ Alcian Blue solution $\left(0.2 \mathrm{~g} \mathrm{~L}^{-1}\right.$ $w / v$ ) for $3 \mathrm{~s}$. Filters were mounted on Cytoclear ${ }^{\circledR}$ slides and stored at $-20^{\circ} \mathrm{C}$ until analysis. Two filters per sample with 30 images each were analyzed using a Zeiss Axio Scope.A1 (Zeiss) equipped with a Zeiss AxioCam MRc. The pictures with a resolution of $1388 \times 1040$ pixels were saved using AxioVision LE64 Rel. 4.8 (Zeiss). All particles larger than $0.2 \mu \mathrm{m}^{2}$ were analyzed. ImageJ was subsequently used for image analysis (Schneider et al., 2012). A filter prepared with $10 \mathrm{~mL}$ Milli-Q water served as a blank. 
Table 1. Name, position and environmental conditions at the stations sampled throughout the cruise. Temperature and salinity were collected at $5 \mathrm{~m}$ water depth.

\begin{tabular}{lrrrrrrr}
\hline Station & Latitude & Longitude & Local time & $\begin{array}{r}\text { Wind speed } \\
{\left[\mathrm{m} \mathrm{s}^{-1}\right]}\end{array}$ & $\begin{array}{r}\text { Water temperature } \\
{\left[{ }^{\circ} \mathrm{C}\right]}\end{array}$ & $\begin{array}{r}\text { Salinity } \\
{[\text { PSU] }}\end{array}$ & $\begin{array}{r}\text { Irradiation } \\
{\left[\mathrm{W} \mathrm{m}^{-2}\right]}\end{array}$ \\
\hline S1 & 41.8918 & 6.3333 & $15: 45$ & 9.7 & 16.4 & 38.2 & 1297.8 \\
S3 & 39.1333 & 7.6835 & $10: 00$ & 2.9 & 18.7 & 37.2 & 2343.2 \\
S4 & 37.9832 & 7.9768 & $10: 30$ & 3.5 & 19.8 & 37.1 & 2270.2 \\
TYRR_1 & 39.34 & 12.5928 & $11: 00$ & 3.4 & 20.3 & 37.8 & 2253.1 \\
TYRR_2 & 39.3398 & 12.5928 & $12: 30$ & 2.5 & 21.1 & 37.7 & 2311.1 \\
S6 & 38.8077 & 14.4997 & $09: 00$ & 5.2 & 20.4 & 37.4 & 2215.5 \\
SAV & 37.8401 & 18.1658 & $12: 00$ & 1.5 & 20.1 & 38.5 & 16.8 \\
S7 & 36.6035 & 18.1658 & $07: 00$ & 2.5 & 21.1 & 38.5 & 1235.3 \\
ION_2 & 35.4892 & 19.7765 & $09: 45$ & 6.4 & 21.2 & 37.9 & 2144.0 \\
S8 & 36.2103 & 16.631 & $07: 45$ & 1.9 & 21.7 & 36.7 & 627.4 \\
FAST_2 & 37.946 & 2.9102 & $08: 30$ & 3.1 & 21.9 & 36.6 & 1787.1 \\
FAST_6 & 37.0466 & 2.9168 & $08: 30$ & 5.1 & & & \\
\hline
\end{tabular}

\subsection{Bacterioplankton and bacterioneuston abundance}

Bacterial cell numbers were determined from $2 \mathrm{~mL}$ samples fixed with $100 \mu \mathrm{L}$ glutaraldehyde (GDA, $1 \%$ final concentration). Samples were stored at $-20^{\circ} \mathrm{C}$ and stained with SYBR Green I (Molecular Probes) to determine abundance using a Becton and Dickinson (BD Biosciences) FACSCalibur flow cytometer equipped with a $488 \mathrm{~nm}$ laser. Bacterial cells were detected by the unique signature in a plot of side scatter (SSC) vs. green fluorescence (FL1). Yellow-green latex beads (Polysciences, $0.5 \mu \mathrm{m}$ ) were used as internal standards.

\subsection{Picophytoplankton and picophytoneuston abundance}

Picophytoplankton and picophytoneuston cell numbers were determined from $2 \mathrm{~mL}$ samples fixed and stored as for bacterial abundances. Samples were filtered through a $50 \mu \mathrm{m}$ filter and analyzed with a flow cytometer (similar to Sect. 2.3). Enumeration of cells was conducted using a high flow rate (approximately $39-41 \mu \mathrm{L} \mathrm{min}^{-1}$ ). The forward- or right-angle light scatter (FALS or RALS) as well as the phycoerythrin- and Chl $a$-related fluorescent signal was used to distinguish the cells. Cell counts were analyzed using the CellQuest Pro software (BD Biosciences). The method used here (fixative addition + slow freezing) follows recommendations by Lepesteur et al. (1993).

\subsection{Total combined carbohydrates}

Samples $(20 \mathrm{~mL})$ for total hydrolyzable carbohydrates (TCHOs) $>1 \mathrm{kDa}$ were filled into precombusted glass vials $\left(8 \mathrm{~h}, 500^{\circ} \mathrm{C}\right)$ and stored at $-20^{\circ} \mathrm{C}$. In the home lab, TCHO analysis was carried out using high-performance anion exchange chromatography with pulsed amperometric detection (HPAEC-PAD) on a Dionex ICS 3000 ion chromatography system (Engel and Händel, 2011). Prior to analysis, samples were desalinated by membrane dialysis $(1 \mathrm{kDa} \mathrm{MWCO}$, Spectra/Por) at $1{ }^{\circ} \mathrm{C}$ for $5 \mathrm{~h}$ and hydrolyzed for $20 \mathrm{~h}$ at $100^{\circ} \mathrm{C}$ in $\mathrm{HCl}(0.8 \mathrm{M}$ final concentration) with subsequent neutralization using acid evaporation $\left(\mathrm{N}_{2}\right.$, for $5 \mathrm{~h}$ at $\left.50^{\circ} \mathrm{C}\right)$. Two replicates were analyzed for each sample.

\subsection{DNA extraction and eukaryote 18S rRNA gene sequencing}

Water samples for sequencing $(400 \mathrm{~mL}$ each) were passed through a $100 \mu \mathrm{m}$ pore size mesh in order to remove metazooplankton that could dominate the $18 \mathrm{~S}$ sequences and were subsequently filtered onto a Durapore membrane (Millipore, $47 \mathrm{~mm}, 0.2 \mu \mathrm{m}$ ) and immediately stored at $-80^{\circ} \mathrm{C}$. In order to improve cell accessibility for the DNA extraction, filters in cryogenic tubes were immersed in liquid nitrogen, and the filter was crushed with a pestle. DNA was extracted according to a modified protocol from Zhou et al. (1996) by Wietz et al. (2015). The protocol included bead-beating, phenol-chloroform-isoamyl alcohol purification, isopropanol precipitation and ethanol washing. An additional protein-removal step by salting was used to avoid protein contamination.

Library preparation and sequencing was conducted at the Integrated Microbiome Resource at Dalhousie University, Halifax, Canada, and is described in detail elsewhere (Comeau et al., 2017). Samples were PCR-amplified in two dilutions $(1: 1$ and $1: 10)$ using the $18 \mathrm{~S}$ rRNA gene primers E572F and E1009R (Comeau et al., 2011). Prior to pooling, samples were cleaned up and normalized using the Invitrogen SequalPrep 96-well plate kit (Thermo Fisher Scientific). Sequencing was conducted according to Comeau et al. (2017) on an Illumina MiSeq using 300+300 bp pairedend V3 chemistry. 
Sequences were processed using the DADA2 pipeline (Callahan et al., 2016), and sequences shorter than $400 \mathrm{bp}$, longer than $444 \mathrm{bp}$, with more than eight homopolymers or any ambiguous bases were discarded. Sequences were aligned with the 18S rRNA gene sequences of the SILVA 132 alignment database (Quast et al., 2013). Subsequently, sequences that aligned outside of most of the dataset and chimeras were removed. Sequences were classified using the SILVA 132 database (Quast et al., 2013) and deposited at the European Nucleotide Archive (ENA accession number PRJEB23731). Sequences were not subsampled, and sequence numbers per sample ranged from 1063 (S8 SML) to 43027 (S5 SML). However, for principal component analysis (PCA), all samples were subsampled down to 1063 sequences.

\subsection{Statistical analyses}

Statistical analyses and maps were produced using $\mathrm{R}(\mathrm{R}$ Core Team, 2014) and bathymetry from NOAA (National Oceanic and Atmospheric Administration). The enrichment factor (EF) was used to compare the concentration of parameter $A$ in the SML ( $[A]_{\mathrm{SML}}$ ) to the concentration in the ULW $\left([A]_{\mathrm{ULW}}\right)$ and was calculated as follows (Eq. 1; World Health Organization, 1995):

$\mathrm{EF}=\frac{[A]_{\mathrm{SML}}}{[A]_{\mathrm{ULW}}}$.

An $\mathrm{EF}>1$ indicates enrichment, $\mathrm{EF}<1$ indicates depletion and $\mathrm{EF}=1$ indicates no difference between the SML and the ULW. The significance of differences between the SML and ULW and between the basins of eukaryote sequences and biogeochemical parameters were tested using the KruskalWallis test and PERMANOVA. Correlations were calculated using Spearman's rank correlation.

\subsection{Data obtained from the ship}

Wind speed, surface water salinity and temperature were obtained at $5 \mathrm{~m}$ depth from the RV Pourquoi pas? system. Radiation measurements were obtained with a LI-COR radiation sensor (Li-200SZ) at wavelengths of 400 to $1100 \mathrm{~nm}$. All parameters were measured every $5 \mathrm{~min}$ during sampling on the zodiac and averaged over the sampling period for statistical analyses (Table 1).

\section{Results}

\subsection{Microbial eukaryote community composition in the SML and ULW}

The eukaryotic communities in the SML and the ULW were similar (ANOSIM, $p=0.039, R=0.1002$ ). However, differences were detected in the eukaryotic community composition (Fig. 2) of the basins sampled (western Mediter- ranean, Tyrrhenian Sea and Ionian Sea). ANOSIM showed that the differences in the eukaryotic community composition were slightly larger across basins than between SML and ULW ( $p=0.0025, R=0.2263$ ). However, the overall diversity and evenness (based on Shannon and Pielou indices) were not significantly different between basins (Fig. S1 in the Supplement).

A total of 16 orders were found in relative abundances over $5 \%$ of the total eukaryotic community in one or more of all 12 stations (Fig. 3). The communities in the SML and ULW at most stations were similar, with Dinophyceae and Syndiniales (Dinoflagellata) and an unidentified Eukaryote class dominating the eukaryotic community. Zooneuston were found in most of the SML samples but rarely $(n=2)$ in the ULW samples. Zooneuston were comprised of Ploimida (Rotifera), Maxillopoda (Cyclopoida and Calanoida) and Scyphozoa (Semaeostomeae).

Myconeuston and mycoplankton were found in high relative abundances in three ULW samples and in the corresponding SML samples (stations 7, 8 and ION_2) in the Ionian Sea. In the ULW of station 7, fungi made up more than half $(54 \%)$ of the total number of retrieved sequences. The vast majority of fungal amplicon sequence variants (ASVs) (64 out of 69) belonged to Ascomycota and Mucoromycota, with the remaining five belonging to the Chytridiomycota $(n=3)$, Basidiomycota and Neocallimastigomycota. All fungal ASVs that were recovered throughout the cruise and their relative abundance are shown in Fig. 4. While fungal ASVs made up a significant amount of sequences in the Ionian Sea (stations to the right of Fig. 4), they were barely detectable at the other stations ( $p=0.014$ for differences in fungal ASVs between basins tested with PERMANOVA).

\subsection{Concentrations and SML enrichments of microorganisms and organic matter}

Bacterial numbers did not show any significant differences between layers (Fig. 5a). In the SML, bacterial abundances ranged from $2.0 \times 10^{5}$ to $1.0 \times 10^{6}$ cells $\mathrm{mL}^{-1}$ with an average

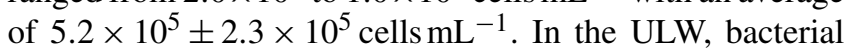
numbers were on average $4.6 \times 10^{5} \pm 1.5 \times 10^{5}$ cells mL $^{-1}$ (range of $2.2 \times 10^{5}$ to $6.9 \times 10^{5}$ cells mL $^{-1}$ ) (Fig. 5).

Picophytoneuston $(0.2-20 \mu \mathrm{m}$ size range) abundance was on average $3.3 \times 10^{3} \pm 1.9 \times 10^{3}$ cells mL $^{-1}$ in the SML, and picophytoplankton abundance was on average $2.3 \times 10^{3} \pm$ $1.7 \times 10^{3}$ cells mL ${ }^{-1}$ in the ULW (range of $1.4 \times 10^{3}$ to $8.5 \times 10^{3}$ cells $\mathrm{mL}^{-1}$ in the SML and $9.5 \times 10^{2}$ to $7.1 \times$ $10^{3}$ cells mL $\mathrm{mL}^{-1}$ in the ULW). Overall, cell counts determined by flow cytometry were significantly higher in the SML than in the ULW ( $p=0.002, n=12$; Fig. 5b).

TEP concentration averaged $1.4 \times 10^{7} \pm 9.7 \times$

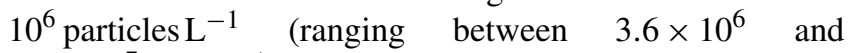
$3.7 \times 10^{7} \mathrm{TEPL}^{-1}$ ) in the SML. In the ULW, the average TEP concentration was $3.6 \times 10^{6} \pm 2.1 \times 10^{6}{\text { particles } L^{-1}}^{-1}$ (ranging between $6.8 \times 10^{5}$ and $7.5 \times 10^{6} \mathrm{TEPL}^{-1}$ ) 


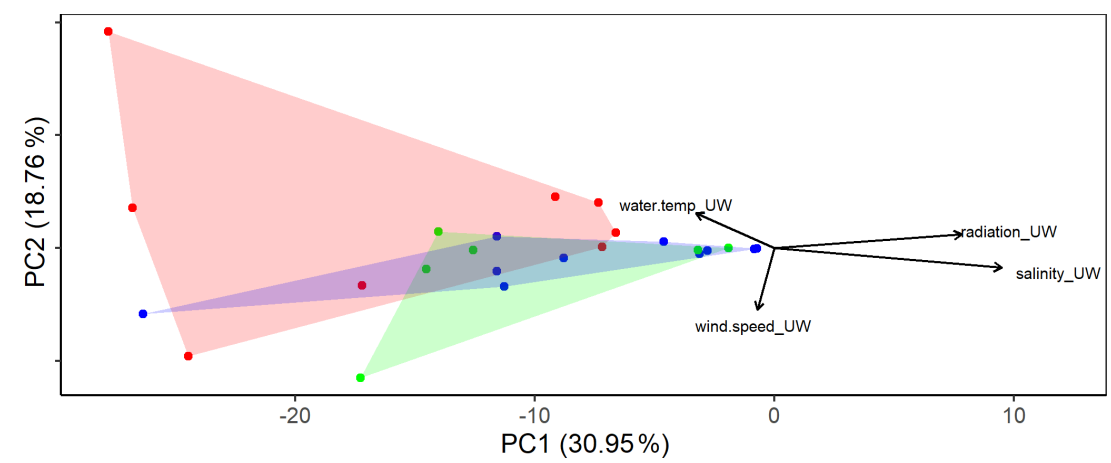

Figure 2. Principal component analysis (PCA) using the eukaryotic community composition at the amplicon sequence variant (ASV) level (see text for a detailed description) with environmental factors plotted. Colors distinguish the three different basins sampled (blue: western basin, green: Tyrrhenian Sea, red: Ionian Sea).
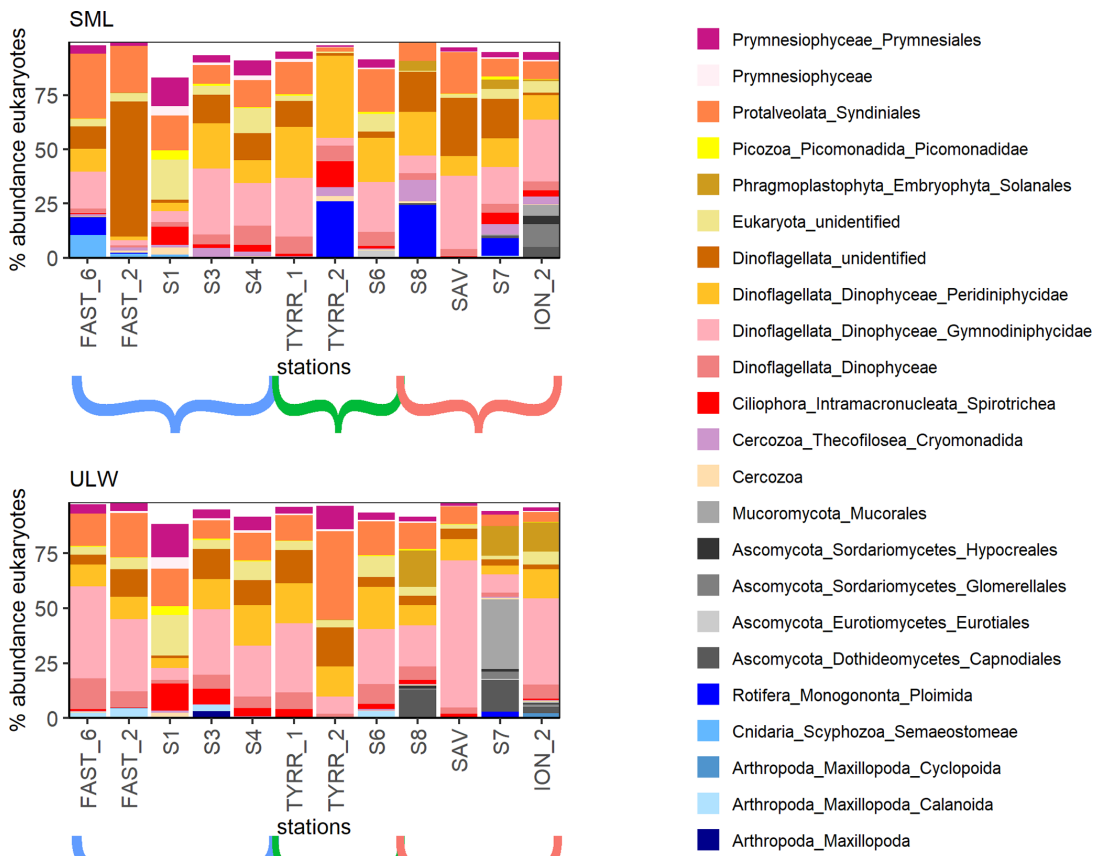

Figure 3. Eukaryotic community composition at the order level (taxa over $5 \%$ in at least one of the samples are displayed). Stations ordered from west to east with brackets indicating the western Mediterranean (blue), the Tyrrhenian Sea (green) and the Ionian Sea (red).

in the ULW. TEP area in the SML was on average $9.7 \times 10^{7} \pm 1.2 \times 10^{8} \mathrm{~mm}^{2} \mathrm{~L}^{-1} \quad\left(1.5 \times 10^{7} \quad\right.$ to $\left.4.5 \times 10^{8} \mathrm{~mm}^{2} \mathrm{~L}^{-1}\right)$. TEP area was lower in the ULW, with an average of $2.3 \times 10^{7} \pm 1.1 \times 10^{7}\left(2.9 \times 10^{6}\right.$ to $\left.3.9 \times 10^{7} \mathrm{~mm}^{2} \mathrm{~L}^{-1}\right)$. Both TEP abundance and area were significantly enriched in the SML (Fig. 5; $p=0.01$ and $p=0.007$, respectively). While irradiation, water temperature and salinity did not correlate with TEP abundance or area, wind speed did have a significant negative correlation with TEP abundance in the SML $\left(R^{2}=-0.73\right)$ and TEP area in the SML $\left(R^{2}=-0.75\right)$ and the enrichment factor for TEP area $\left(R^{2}=-0.63\right)$.
TCHO concentrations were similar between the SML and ULW (Fig. 5e), with no significant differences between depths $(778 \pm 294 \mathrm{nM}$ (range 562 to $1684 \mathrm{nM}$ ) in the SML and $605 \pm 97 \mathrm{nM}$ (range 525 to $885 \mathrm{nM}$ in the ULW).

\section{Discussion}

\subsection{Eukaryotic diversity in the surface of the Mediterranean Sea}

The eukaryotic community composition between the SML and the ULW differed only slightly, with higher horizontal heterogeneity and significant differences between the com- 


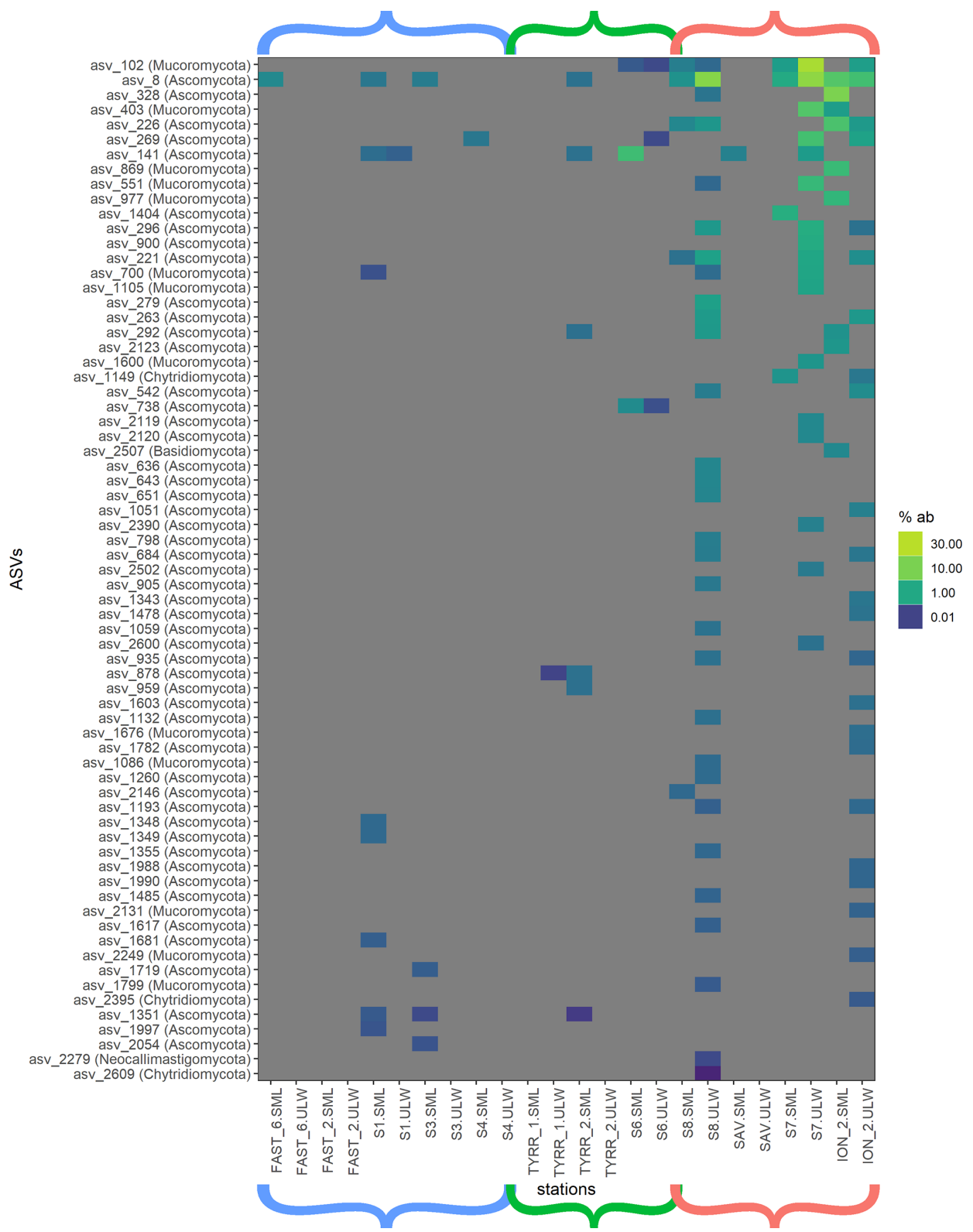

Figure 4. Heat map of fungal relative ASV abundances in all sequences samples. Color brackets indicate the different basins as in Figs. 3 and 2. Grey corresponds to the absence of the ASV in the respective sample.

munities of the western, Tyrrhenian and Ionian basins. The Shannon diversity did not differ significantly between depths or basins; however, a slight decrease in species richness from west to east could be observed (Fig. S1), possibly related to the transition from oligotrophic to ultra-oligotrophic conditions given the more pronounced water exchange with the Atlantic in the western basin (Reddaway and Bigg, 1996).

No diatoms were present at high relative abundances in our samples. In seasonal studies in the Mediterranean Sea, diatom contribution can be significant during blooms in March and April, but later in the year, as the water column stratifies, their contribution decreases (Marty et al., 2002). Even though diatoms most likely were not dominant in the samples, the extremely low abundance $(<1 \%)$ of diatoms in the samples might also indicate a bias of the primers used or removal of larger cells and aggregates during the pre-filtration step. Another potential bias is the dominance of dinoflagellate genera (Fig. 3). Dinoflagellates have a large number of $18 \mathrm{~S}$ rRNA gene copies in comparison to other phytoplankton groups, and therefore their abundance in 18S rRNA gene sequencing is often overestimated (Godhe et al., 2008; Guo et al., 2016).

Previous studies suggested various factors that potentially drive the phytoplankton community composition. In addition 

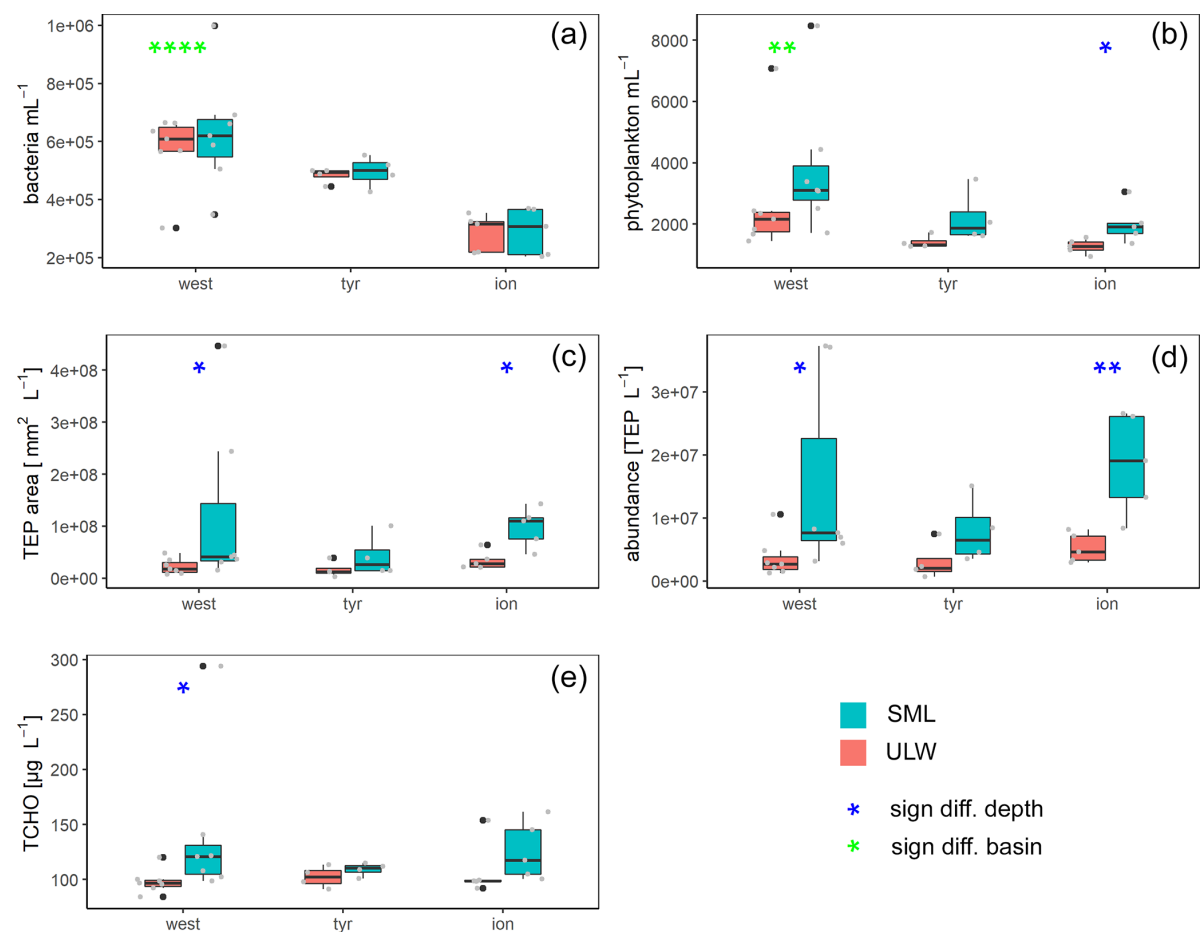

Figure 5. Box plots of bacteria (a) and phytoplankton (b) abundance as well as area (c) and concentrations (d) of transparent exopolymer particles (TEPs) and total carbohydrates (TCHO) (e) for each basin in the Mediterranean Sea: western basin (west), Tyrrhenian Sea (tyr) and Ionian Sea (ion). Blue stars mark significant SML enrichment/depletion; green stars mark significant differences between the three basins (Kruskal-Wallis tests used for significance levels). Significance levels: ${ }^{*} p<0.05,{ }^{* *} p<0.01,{ }^{* * *} p<0.001,{ }^{* * * *} p<0.0001$. Black dots correspond to outliers and grey dots to the measured values and concentrations.

to buoyancy of cells, high levels of UV radiation could potentially cause damage by photoinhibition. While dinoflagellates, one of the dominating phytoplankton groups, can produce photoprotective compounds, including mycosporinelike amino acids (MAAs) (Carreto et al., 1990; Häder et al., 2007), they can still be inhibited by high UV radiation (Ekelund, 1991). In the present study, inhibition by UV radiation is not indicated in the data since phytoplankton was enriched in the SML despite high radiation values (e.g., stations 4 and 7; Table 1). At the same time, TEP were significantly enriched during this sampling campaign while the phytoplankton community did not show significant differences. Previous studies suggested that TEP can protect phytoplankton and bacteria from UV radiation (Elasri and Miller, 1999; Ortega-Retuerta et al., 2009). Process oriented studies would be needed to determine whether TEP production was higher in the SML due to UV protection of phytoneuston or whether TEP formation rates were higher in the SML due to wind and wave shear at the surface (Carlson, 1993; Cunliffe et al., 2013).

\subsection{Fungi in the Ionian Sea}

Fungi were prevalent in the Ionian Sea (more than half of the sequences retrieved at one station), whereas they were scarce in the western basin and the Tyrrhenian Sea (Figs. 3 and 4). Most of the fungal ASVs present in the Ionian Sea belonged to Ascomycota and Mucoromycota. The question arises as to what drives the higher fungal relative abundances in this region of the Mediterranean Sea. While fungi, like dinoflagellates and other eukaryotic groups, can have varying amounts of 18S rDNA gene copy numbers, the patchy distribution of fungi found in this study makes a consistent bias unlikely. Marine fungi can live a saprotrophic lifestyle, degrading and recycling high-molecular-weight organic matter (Chrismas and Cunliffe, 2020; Cunliffe et al., 2017) and potentially competing with functionally similar bacteria. Some marine fungi are also phytoplankton parasites, potentially altering phytoplankton community composition through selective parasitism (Amend et al., 2019; Grossart et al., 2019). At present, we have a very limited understanding of the diversity and functional role of fungi in the SML (myconeuston). One previous study of the coastal myconeuston in the western English Channel off Plymouth (UK) showed that the SML was dominated by both Ascomycota and Basidiomycota (Taylor and Cunliffe, 2014), while our results support the dominance of Ascomycota in the SML.

So far, not many studies have looked at fungi in LNLC regions. A global comparison of fungal distribution (Hassett et al., 2020) has found that fungal diversity determined 
by amplicon sequencing varies between different oceanic regions, with Exophiala, belonging to Ascomycota, dominating the Ligurian Sea and an unclassified Ascomycota being the most abundant taxon in other regions.

ASVs identified as Solanales (Nicotiana) had quite high relative abundances in the easternmost stations. Since Solanales are land plants, presence of their DNA could suggest a terrestrial influence on the Ionian Sea, linked to wet or dry deposition that occurred before and/or during our sampling period in this basin. This is also corroborated by air mass trajectory backtracking using the Hybrid SingleParticle Lagrangian Integrated Trajectory (HYSPLIT) model (Fig. S3), which showed that aerosols were most likely of continental origin (Fu et al., 2021). This is also confirmed by atmospheric measurements indicating that chemical composition of dry and wet depositions were influenced by Eastern European air masses (Desboeufs et al., 2021). Station FAST_2 in the western basin was highly influenced by dust input in the area (Guieu et al., 2020; Tovar-Sánchez et al., 2020). This coincided not only with a strong increase in TEP abundance in the SML, but also with a distinct increase in the relative abundance of unidentified dinoflagellates in the SML (Fig. 3). The details of the impact of dust input on the organic matter and microbial community composition in the SML and ULW are discussed elsewhere (Anja Engel et al., unpublished data). However, no fungi were found at station FAST_2 either in the SML or in the ULW (Fig. 4), showing that dust input does not necessarily deposit fungi to the surface ocean; this potentially also holds true for the Ionian Sea. In addition to atmospheric inputs, riverine inputs can also influence the Mediterranean Sea (Martin et al., 1989). However, the Ionian Sea itself does not experience vast riverine input, and riverine influence is less pronounced in the open sea, making riverine sources of Mycophyta unlikely. Ascomycota and Mucoromycota have been recovered from a variety of marine environments (Bovio, 2019; Grossart et al., 2019; Hassett et al., 2019), implying that they also might be thriving in the SML of the Mediterranean Sea rather than originating solely from terrestrial sources.

Overall, the most abundant fungal ASV in the Ionian Sea (ASV 8) was identified as belonging to genus Cladosporium, which has been found in marine environments before (Cunliffe et al., 2017). Another explanation for the high relative abundance of fungi in the Ionian Sea might be that they are more adapted to dealing with the low-nutrient conditions found in the more eastern basin of the Mediterranean Sea.

Bacterial and microalgal numbers determined by flow cytometry decreased significantly from west to east, with bacteria showing the largest decline (Tovar-Sánchez et al., 2020). While total microalgal abundances determined by flow cytometry were low in the SML and in the ULW, they were comparable to other studies on phytoplankton abundance in the SML of the Mediterranean Sea (Joux et al., 2006). The microalgal numbers between 5 and $200 \mathrm{~m}$ water depth (data not shown) were higher than at the air-sea interface. Even though overall bacterial numbers decrease, further molecular analyses would be needed to determine if the bacterial community is changing from west to east and if certain bacterial taxa can benefit from the ultra-oligotrophic conditions. In contrast to bacteria and phytoplankton, spatial trends in TCHO and TEP, as well as DOC in the SML and dissolved organic carbon (DOC) and particulate organic carbon (POC) in the ULW, did not show significant differences between the Ionian Sea and the other basins (Freney et al., 2020; Trueblood et al., 2020). TEPs are often enriched in the SML (Engel and Galgani, 2016; Jennings et al., 2017; Wurl et al., 2009; Wurl and Holmes, 2008), in particular over oligotrophic regions (Jennings et al., 2017; Zäncker et al., 2017). This is in good accordance with trends observed in the present study (Durrieu de Madron et al., 2011; Fogg, 1995; Wikner and Hagstrom, 1988). Wind speed correlated negatively with TEP abundance and area in the SML, showing that wind can negatively affect TEP concentrations at the airsea interface as has been previously suggested (Sun et al., 2018).

Since exchange of water with the Atlantic is most pronounced in the western basin and an anti-estuarine circulation prevails in the Mediterranean Sea, nutrient limitation increases eastwards. TEP production has been shown to be independent of stoichiometric ratios in the surrounding water in a previous study (Corzo et al., 2000). Since light limitation rarely occurs in the SML and TEP can potentially protect phytoplankton from light damage (Elasri and Miller, 1999; Ortega-Retuerta et al., 2009), phytoplankton might still photosynthesize and excrete carbohydrates that assemble to TEP. This would not only explain the lack of difference in TEP abundances between basins, but also TCHO concentrations. TCHO can also be produced by cell lysis (due to nutrient depletion).

TCHO and TEP could also provide available substrate and microhabitats for marine fungi with reduced competition by bacteria in the Ionian Sea. Malassezia and Cladosporium have been shown to assimilate carbon derived from TEP-associated algal polysaccharides in the English Channel (Cunliffe et al., 2017), highlighting that Cladosporium and other fungi might be able to profit from the decreased bacterial competition in the Ionian Sea. Further, previous studies have shown that the eastern Mediterranean Sea contains higher concentrations of organic pollutants (Berrojalbiz et al., 2011a, b), while a Cladosporium strain has the capacity to degrade polycyclic aromatic hydrocarbons (Birolli et al., 2018), highlighting another potential substrate for the fungi detected in the Ionian Sea.

\section{Conclusions}

The present study shows that bacteria and picophytoplankton numbers decrease from west to east in the Mediterranean $\mathrm{Sea}$; in contrast, organic matter such as microgels and TCHO 
are still prevalent in surface waters. Our findings from the Ionian Sea suggest that accumulation of organic substrates in the surface under oligotrophic conditions may favor certain taxa, such as fungi which can benefit from decreased competition by bacteria. LNLC regions, where phytoplankton and bacterial counts are typically low but TEP enrichment is high in the SML, might be a specific ecosystem where fungi are able to thrive and to control organic matter degradation.

Data availability. All biogeochemical data will be made available at the French INSU/CNRS LEFE CYBER database (data manager, webmaster: Catherine Schmechtig, http://www.obs-vlfr.fr/proof/ php/PEACETIME/peacetime.php, last access: 3 March 2021). All sequence data are available at the European Nucleotide Archive (ENA accession number PRJEB23731).

Special issue statement. This article is part of the special issue "Atmospheric deposition in the low-nutrient-low-chlorophyll (LNLC) ocean: effects on marine life today and in the future (ACP/BG interjournal SI)". It is not associated with a conference.

Supplement. The supplement related to this article is available online at: https://doi.org/10.5194/bg-18-2107-2021-supplement.

Author contributions. BZ, MC and AE wrote the paper and contributed to the data analysis. BZ participated in the sample treatment.

Competing interests. The authors declare that they have no conflict of interest.

Acknowledgements. We would like to thank the chief scientist, Cécile Guieu and Karine Desboeufs, of the PEACETIME cruise on the RV Pourquoi pas?. We would also like to thank the captain and crew of the Pourquoi pas? for technical assistance in the field. This work is a contribution of the PEACETIME project (http://peacetime-project.org, last access: 3 March 2021), a joint initiative of the MERMEX and ChArMEx components supported by CNRS-INSU, IFREMER, CEA, and MétéoFrance as part of the program MISTRALS coordinated by INSU (https://doi.org/10.17600/17000300).

We thank Jon Roa for his help in analyzing the total combined carbohydrates and Tania Klüver for analyzing the flow cytometry cell counts. We would also like to thank ISOS (Kiel, Germany) for funding part of this work with a $\mathrm{PhD}$ miniproposal grant.

Financial support. This research has been supported by the CNRS-INSU, IFREMER, CEA, Météo-France (https://doi.org/10.17600/17000300) and the Integrated School of Ocean Sciences (PhD miniproposal).
The article processing charges for this open-access publication were covered by a Research Centre of the Helmholtz Association.

Review statement. This paper was edited by Christine Klaas and reviewed by three anonymous referees.

\section{References}

Agogué, H., Casamayor, E. O., Bourrain, M., Obernosterer, I., Joux, F., Herndl, G. J., and Lebaron, P.: A survey on bacteria inhabiting the sea surface microlayer of coastal ecosystems, FEMS Microbiol. Ecol., 54, 269-280, https://doi.org/10.1016/j.femsec.2005.04.002, 2005.

Alldredge, A. L., Passow, U., and Logan, B. E.: The abundance and significance of a class of large, transparent organic particles in the ocean, Deep-Sea Res. Pt. I, 40, 1131-1140, 1993.

Amend, A., Burgaud, G., Cunliffe, M., Edgcomb, V. P., Ettinger, C. L., Gutierrez, M. H., Heitman, J., Hom, E. F. Y., Ianiri, G., Jones, A. C., Kagami, M., Picard, K. T., Quandt, C. A., Raghukumar, S., Riquelme, M., Stajich, J., Vargas-muñiz, J., Walker, A. K., Yarden, O., and Gladfelter, A. S.: Fungi in the Marine Environment: Open Questions and Unsolved Problems, MBio, 10, 1-15, 2019.

Apts, J. T. H. C. W.: Photosynthetic carbon reduction: high rates in the sea-surface microlayer, Mar. Biol., 101, 411-417, https://doi.org/10.1007/bf00428138, 1989.

Azetsu-Scott, K. and Passow, U.: Ascending marine particles: Significance of transparent exopolymer particles (TEP) in the upper ocean, Limnol. Oceanogr., 49, 741-748, https://doi.org/10.4319/lo.2004.49.3.0741, 2004.

Berrojalbiz, N., Dachs, J., Ojeda, M. J., Valle, M. C., Jiménez, J. C., Wollgast, J., Ghiani, M., Hanke, G., and Zaldivar, J. M.: Biogeochemical and physical controls on concentrations of polycyclic aromatic hydrocarbons in water and plankton of the Mediterranean and Black Seas, Global Biogeochem. Cy., 25, 1-14, https://doi.org/10.1029/2010GB003775, 2011a.

Berrojalbiz, N., Dachs, J., Vento, S. Del, Jos, M., Valle, M. C., Castro-jim, J., Mariani, G., Wollgast, J., and Hanke, G.: Persistent Organic Pollutants in Mediterranean Seawater and Processes Affecting Their Accumulation in Plankton, Environ. Sci. Technol., 45, 4315-4322, https://doi.org/10.1021/es103742w, 2011b.

Birolli, W. G., Santos, D. D. A., Alvarenga, N., and Garcia, A. C. F. S.: Biodegradation of anthracene and several PAHs by the marine-derived fungus Cladosporium sp. CBMAI 1237 Biodegradation of anthracene and several PAHs by the marine-derived fungus Cladosporium sp. CBMAI 1237, Mar. Pollut. Bull., 192, 525-533, https://doi.org/10.1016/j.marpolbul.2017.10.023, 2018.

Bovio, E.: Marine fungi from sponges: biodiversity, chemodiversity and biotechnological applications, Diss. Université Côte d'Azur, Università degli studi (Turin, Italy), 2019.

Callahan, B. J., Mcmurdie, P. J., Rosen, M. J., Han, A. W., Johnson, A. J., and Holmes, S. P.: DADA2: High resolution sample inference from Illumina amplicon data, Nat. Methods, 13, 581583, https://doi.org/10.1038/nmeth.3869, 2016. 
Carlson, D.: The Early Diagenesis of Organic Matter: Reaction at the Air-Sea Interface, in: Organic Geochemistry 1, 225-268, Springer, Boston, MA, 1993.

Carreto, J. I., Carignan, M. O., Daleo, G., and DeMarco, S. G.: Ocurrence of mycosporine-like amino acids in the red-tide dinoflagellate Alexandrium excavatum:uvphotoprotective compounds?, J. Plankton Res., 12, 909-921, https://doi.org/10.1093/plankt/12.5.909, 1990.

Chin, W.-C., Orellana, M. V., and Verdugo, P.: Spontaneous assembly of marine dissolved organic matter into polymer gels, Nature, 391, 568-572, 1998.

Chrismas, N. and Cunliffe, M.: Depth-dependent mycoplankton glycoside hydrolase gene activity in the open ocean - evidence from the Tara Oceans eukaryote metatranscriptomes, ISME J., 14, 2361-2365, https://doi.org/10.1038/s41396-0200687-2, 2020.

Comeau, A. M., Li, W. K. W., Tremblay, J. É., Carmack, E. C., and Lovejoy, C.: Arctic ocean microbial community structure before and after the 2007 record sea ice minimum, PLoS One, 6, e27492, https://doi.org/10.1371/journal.pone.0027492, 2011.

Comeau, A. M., Douglas, G. M., and Langille, M. G. I.: Microbiome Helper: a Custom and Streamlined Workflow for Microbiome Research, mSystems, 2, e00127-16, https://doi.org/10.1128/mSystems.00127-16, 2017.

Corzo, A., Morillo, J. A., and Rodriquez, S.: Production of transparent exopolymer particles (TEP) in cultures of Chaetoceros calcitrans under nitrogen limitation, Aquat. Mar. Ecol., 23, 63-72, 2000 .

Cunliffe, M. and Murrell, J. C.: The sea-surface microlayer is a gelatinous biofilm., ISME J., 3, 1001-1003, https://doi.org/10.1038/ismej.2009.69, 2009.

Cunliffe, M. and Murrell, J. C.: Eukarya 18S rRNA gene diversity in the sea surface microlayer: implications for the structure of the neustonic microbial loop, ISME J., 4, 455-458, https://doi.org/10.1038/ismej.2009.133, 2010.

Cunliffe, M. and Wurl, O.: Guide to best practices to study the ocean's surface, Plymouth, available at: https: //repository.oceanbestpractices.org/bitstream/handle/11329/261/ SCOR_GuideSeaSurface_2014.pdf?sequence=1\&isAllowed=y (last access: 3 March 2021), 2014.

Cunliffe, M., Engel, A., Frka, S., Gašparović, B., Guitart, C., Murrell, J. C., Salter, M., Stolle, C., UpstillGoddard, R., and Wurl, O.: Sea surface microlayers: A unified physicochemical and biological perspective of the air-ocean interface, Prog. Oceanogr., 109, 104-116, https://doi.org/10.1016/j.pocean.2012.08.004, 2013.

Cunliffe, M., Hollingsworth, A., Bain, C., Sharma, V., and Taylor, J. D.: Algal polysaccharide utilisation by saprotrophic planktonic marine fungi, Fungal Ecol., 30, 135-138, https://doi.org/10.1016/j.funeco.2017.08.009, 2017.

Desboeufs, K., Fu, F., Bressac, M., Tovar-Sánchez, A., Triquet, S., Doussin, J.-F., Giorio, C., Rodri'guez-Romero, A., Wagener, T., Dulac, F., and Guieu, C.: Wet deposition in the remote western and central Mediterranean: A source of nutrients and trace metals for the marine biosphere?, Atmos. Chem. Phys., in preparation, 2021.

Durrieu de Madron, X., Guieu, C., Sempéré, R., Conan, P., Cossa, D., D’Ortenzio, F., Estournel, C., Gazeau, F., Rabouille, C., Stemmann, L., Bonnet, S., Diaz, F., Koubbi, P.,
Radakovitch, O., Babin, M., Baklouti, M., Bancon-Montigny, C., Belviso, S., Bensoussan, N., Bonsang, B., Bouloubassi, I., Brunet, C., Cadiou, J. F., Carlotti, F., Chami, M., Charmasson, S., Charrière, B., Dachs, J., Doxaran, D., Dutay, J. C., Elbaz-Poulichet, F., Eléaume, M., Eyrolles, F., Fernandez, C., Fowler, S., Francour, P., Gaertner, J. C., Galzin, R., Gasparini, S., Ghiglione, J. F., Gonzalez, J. L., Goyet, C., Guidi, L., Guizien, K., Heimbürger, L. E., Jacquet, S. H. M., Jeffrey, W. H., Joux, F., Le Hir, P., Leblanc, K., Lefèvre, D., Lejeusne, C., Lemé, R., Loÿe-Pilot, M. D., Mallet, M., Méjanelle, L., Mélin, F., Mellon, C., Mérigot, B., Merle, P. L., Migon, C., Miller, W. L., Mortier, L., Mostajir, B., Mousseau, L., Moutin, T., Para, J., Pérez, T., Petrenko, A., Poggiale, J. C., Prieur, L., PujoPay, M., Pulido-Villena, Raimbault, P., Rees, A. P., Ridame, C., Rontani, J. F., Ruiz Pino, D., Sicre, M. A., Taillandier, V., Tamburini, C., Tanaka, T., Taupier-Letage, I., Tedetti, M., Testor, P., Thébault, H., Thouvenin, B., Touratier, F., Tronczynski, J., Ulses, C., Van Wambeke, F., Vantrepotte, V., Vaz, S., and Verney, R.: Marine ecosystems' responses to climatic and anthropogenic forcings in the Mediterranean, Prog. Oceanogr., 91, 97-166, https://doi.org/10.1016/j.pocean.2011.02.003, 2011.

Ekelund, N. G. A.: The Effects of UV-B Radiation on Dinoflagellates, J. Plant Physiol., 138, 274-278, 1991.

Engel, A. and Händel, N.: A novel protocol for determining the concentration and composition of sugars in particulate and in high molecular weight dissolved organic matter (HMW-DOM) in seawater, Mar. Chem., 127, 180-191, 2011.

Elasri, M. O. and Miller, R. V: Study of the Response of a Biofilm Bacterial Community to UV Radiation Study of the Response of a Biofilm Bacterial Community to UV Radiation, Appl. Environ. Microb., 65, 2025-2031, 1999.

Engel, A.: The role of transparent exopolymer particles (TEP) in the increase in apparent particle stickiness (alpha) during the decline of a diatom bloom, J. Plankton Res., 22, 485-497, https://doi.org/10.1093/plankt/22.3.485, 2000.

Engel, A.: Determination of marine gel particles, in: Practical Guidelines for the Analysis of Seawater, edited by: Wurl, O., CRC Press Taylor \& Francis Group, Boca Raton, FL, 125-142, 2009.

Engel, A. and Galgani, L.: The organic sea-surface microlayer in the upwelling region off the coast of Peru and potential implications for air-sea exchange processes, Biogeosciences, 13, 989-1007, https://doi.org/10.5194/bg-13-989-2016, 2016.

Engel, A., Thoms, S., Riebesell, U., Rochelle-Newall, E., and Zondervan, I.: Polysaccharide aggregation as a potential sink of marine dissolved organic carbon, Nature, 428, 929-932, https://doi.org/10.1038/nature02453, 2004.

Engel, A., Bange, H. W., Cunliffe, M., Burrows, S. M., Friedrichs, G., Galgani, L., Herrmann, H., Hertkorn, N., Johnson, M., Liss, P. S., Quinn, P. K., Schartau, M., Soloviev, A., Stolle, C., Upstill-Goddard, R. C., van Pinxteren, M., and Zäncker, B.: The Ocean's Vital Skin: Toward an Integrated Understanding of the Sea Surface Microlayer, Front. Mar. Sci., 4, 165, https://doi.org/10.3389/fmars.2017.00165, 2017.

Fogg, G. E.: Some comments on picoplankton and its importance in the pelagic ecosystem, Aquat. Microb. Ecol., 9, 33-39, https://doi.org/10.3354/ame009033, 1995.

Freney, E., Sellegri, K., Nicosia, A., Trueblood, J. T., Rinaldi, M., Williams, L. R., Prévôt, A. S. H., Thyssen, M., Grégori, G., 
Haëntjens, N., Dinasquet, J., Obernosterer, I., Van-Wambeke, F., Engel, A., Zäncker, B., Desboeufs, K., Asmi, E., Timmonen, H., and Guieu, C.: Mediterranean nascent sea spray organic aerosol and relationships with seawater biogeochemistry, Atmos. Chem. Phys. Discuss. [preprint], https://doi.org/10.5194/acp-2020-406, in review, 2020.

Fu, F., Desboeufs, K., Triquet, S., Doussin, J.-F., Giorio, C., Formenti, P., Feron, A., Maisonneuve, F., and Dulac, F.: Aerosol characterisation and quantification of trace element atmospheric dry deposition fluxes in remote Mediterranean Sea during PEACETIME cruise, Atmos. Chem. Phys., in preparation, 2021.

Garzoli, L., Gnavi, G., Tamma, F., Tosi, S., Varese, G. C., and Picco, A. M.: Sink or swim: Updated knowledge on marine fungi associated with wood substrates in the Mediterranean Sea and hints about their potential to remediate hydrocarbons, Prog. Oceanogr., 137, 140-148, https://doi.org/10.1016/j.pocean.2015.05.028, 2015.

Gladfelter, A. S., James, T. Y., and Amend, A. S.: Marine fungi, Curr. Biol., 29, R191-R195, 2019.

Gnavi, G., Garzoli, L., Poli, A., Prigione, V., Burgaud, G., and Varese, G. C.: The culturable mycobiota of Flabellia petiolata: First survey of marine fungi associated to a Mediterranean green alga, PLoS One, 12, 1-20, https://doi.org/10.1371/journal.pone.0175941, 2017.

Godhe, A., Asplund, M. E., Härnström, K., Saravanan, V., Tyagi, A., and Karunasagar, I.: Quantification of diatom and dinoflagellate biomasses in coastal marine seawater samples by real-time PCR, Appl. Environ. Microb., 74, 7174-7182, https://doi.org/10.1128/AEM.01298-08, 2008.

Grossart, H.-P., Van den Wyngaert, S., Kagami, M., Wurzbacher, C., Cunliffe, M., and Rojas-Jimenez, K.: Fungi in aquatic ecosystems, Nat. Rev. Microbiol., 17, 339-354, 2019.

Guieu, C., D’Ortenzio, F., Dulac, F., Taillandier, V., Doglioli, A., Petrenko, A., Barrillon, S., Mallet, M., Nabat, P., and Desboeufs, K.: Introduction: Process studies at the air-sea interface after atmospheric deposition in the Mediterranean Sea - objectives and strategy of the PEACETIME oceanographic campaign (May-June 2017), Biogeosciences, 17, 5563-5585, https://doi.org/10.5194/bg-17-5563-2020, 2020.

Guo, L., Sui, Z., and Liu, Y.: Quantitative analysis of dinoflagellates and diatoms community via Miseq sequencing of actin gene and v9 region of $18 \mathrm{~S}$ rDNA, Sci. Rep.-UK, 6, 1-9, https://doi.org/10.1038/srep34709, 2016.

Häder, D.-P., Kumar, H. D., Smith, R. C., and Worrest, R. C.: Effects of solar UV radiation on aquatic ecosystems and interactions with climate change, Photochem. Photobio. S., 6, 267-285, https://doi.org/10.1039/B700020K, 2007.

Hardy, J. T. and Apts, C. W.: The sea-surface microlayer: phytoneuston productivity and effects of atmospheric particulate matter, Mar. Biol., 82, 293-300, 1984.

Hardy, J. T., Coley, J. A., Antrim, L. D., and Kiesser, S. L.: A hydrophobic large-volume sampler for collecting aquatic surface microlayers: characterization and comparison with the glass plate method, Can. J. Fish. Aquat. Sci., 45, 822-826, 1988.

Harvey, G.: Microlayer collection from the sea surface: a new method and intial results, Limnol. Oceanogr., 11, 608-613, 1966.

Hassett, B. T., Borrego, E. T., Vonnahme, T. R., Rämä, T., Kolomiets, M. V., and Gradinger, R.: Arctic marine fungi: Biomass, functional genes, and putative ecological roles, ISME J., 13, 1484-1496, 2019.

Hassett, B. T., Vonnahme, T. R., Peng, X., and Jones, E. B. G.: Global diversity and geography of planktonic marine fungi, Bot. Mar., 63, 121-139, 2020.

Jennings, M. K., Passow, U., Wozniak, A. S., and Hansell, D. A.: Distribution of transparent exopolymer particles (TEP) across an organic carbon gradient in the western North Atlantic Ocean, Mar. Chem., 190, 1-12, https://doi.org/10.1016/j.marchem.2017.01.002, 2017.

Joux, F., Agogue, H., Obernosterer, I., Dupuy, C., Reinthaler, T., Herndl, G. J., and Lebaron, P.: Microbial community structure in the sea surface microlayer at two contrasting sites in the northwestern Mediterranean Sea, Aquat. Microb. Ecol., 42, 91-104, https://doi.org/10.3354/ame042091, 2006.

Krom, M. D., Herut, B., and Mantoura, R. F. C.: Nutrient budget for the Eastern Mediterranean: Implications for phosphorus limitation, Limnol. Oceanogr., 49, 1582-1592, https://doi.org/10.4319/lo.2004.49.5.1582, 2004.

Lepesteur, M., Martin, J. M., and Fleury, A.: A comparative study of d methods for phytoplank flow cytometry, Mar. Ecol. Prog. Ser., 93, 55-63, 1993.

Liss, P. S. and Duce, R. A.: The sea surface and global change, Cambridge University Press, Cambridge, 2005.

Martin, J. M., Elbaz-Poulichet, F., Guieu, C., Loÿe-Pilot, M. D., and Han, G.: River versus atmospheric input of material to the mediterranean sea: an overview, Mar. Chem., 28, 159-182, https://doi.org/10.1016/0304-4203(89)90193-X, 1989.

Marty, J. C., Chiavérini, J., Pizay, M. D., and Avril, B.: Seasonal and interannual dynamics of nutrients and phytoplankton pigments in the western Mediterranean Sea at the DYFAMED timeseries station (1991-1999), Deep-Res. Pt. II, 49, 1965-1985, https://doi.org/10.1016/S0967-0645(02)00022-X, 2002.

Mermex Group, T., Durrieu de Madron, X., Guieu, C., Sempéré, R., Conan, P., Cossa, D., D’Ortenzio, F., Estournel, C., Gazeau, F., Rabouille, C., Stemmann, L., Bonnet, S., Diaz, F., Koubbi, P., Radakovitch, O., Babin, M., Baklouti, M., Bancon-Montigny, C., Belviso, S., Bensoussan, N., Bonsang, B., Bouloubassi, I., Brunet, C., Cadiou, J. F., Carlotti, F., Chami, M., Charmasson, S., Charrière, B., Dachs, J., Doxaran, D., Dutay, J. C., Elbaz-Poulichet, F., Eléaume, M., Eyrolles, F., Fernandez, C., Fowler, S., Francour, P., Gaertner, J. C., Galzin, R., Gasparini, S., Ghiglione, J. F., Gonzalez, J. L., Goyet, C., Guidi, L., Guizien, K., Heimbürger, L. E., Jacquet, S. H. M., Jeffrey, W. H., Joux, F., Le Hir, P., Leblanc, K., Lefèvre, D., Lejeusne, C., Lemé, R., Loÿe-Pilot, M. D., Mallet, M., Méjanelle, L., Mélin, F., Mellon, C., Mérigot, B., Merle, P. L., Migon, C., Miller, W. L., Mortier, L., Mostajir, B., Mousseau, L., Moutin, T., Para, J., Pérez, T., Petrenko, A., Poggiale, J. C., Prieur, L., PujoPay, M., Pulido-Villena, Raimbault, P., Rees, A. P., Ridame, C., Rontani, J. F., Ruiz Pino, D., Sicre, M. A., Taillandier, V., Tamburini, C., Tanaka, T., Taupier-Letage, I., Tedetti, M., Testor, P., Thébault, H., Thouvenin, B., Touratier, F., Tronczynski, J., Ulses, C., Van Wambeke, F., Vantrepotte, V., Vaz, S., and Verney, R.: Marine ecosystems' responses to climatic and anthropogenic forcings in the Mediterranean, Prog. Oceanogr., 91, 97 166, https://doi.org/10.1016/j.pocean.2011.02.003, 2011.

Mopper, K., Zhou, J., Ramana, K. S., Passow, U., Dam, H. G., and Drapeau, D. T.: The role of surface active carbohydratesin the 
flocculation of a diatom bloom in a mesocosm, Deep-Sea Res. Pt. I, 42, 43-73, 1995.

Naumann, E.: Über das Neuston des Süsswassers, Biol. Cent., 37, 98-106, 1917.

Obernosterer, I., Catala, P., Lami, R., Caparros, J., Ras, J., Bricaud, A., Dupuy, C., van Wambeke, F., and Lebaron, P.: Biochemical characteristics and bacterial community structure of the sea surface microlayer in the South Pacific Ocean, Biogeosciences, 5, 693-705, https://doi.org/10.5194/bg-5-693-2008, 2008.

Ortega-Retuerta, E., Passow, U., Duarte, C. M., and Reche, I.: Effects of ultraviolet B radiation on (not so) transparent exopolymer particles, Biogeosciences, 6, 3071-3080, https://doi.org/10.5194/bg-6-3071-2009, 2009.

Passow, U.: Transparent Exopolymer Particles in Aquatic Environments, Prog. Oceanogr., 55, 287-333, https://doi.org/10.1016/S0079-6611(02)00138-6, 2002.

Passow, U. and Alldredge, A. L.: Aggregation of a diatom bloom in a mesocosm: The role of transparent exopolymer particles (TEP), Deep-Res. Pt. II, 42, 99-109, https://doi.org/10.1016/09670645(95)00006-C, 1995.

Ploug, H.: Cyanobacterial surface blooms formed by Aphanizomenon sp. and Nodularia spumigena in the Baltic Sea: Small-scale fluxes, $\mathrm{pH}$, and oxygen microenvironments, Limnol. Oceanogr., 53, 914-921, https://doi.org/10.4319/lo.2008.53.3.0914, 2008.

Pujo-Pay, M., Conan, P., Oriol, L., Cornet-Barthaux, V., Falco, C., Ghiglione, J.-F., Goyet, C., Moutin, T., and Prieur, L.: Integrated survey of elemental stoichiometry $(\mathrm{C}, \mathrm{N}, \mathrm{P})$ from the western to eastern Mediterranean Sea, Biogeosciences, 8, 883899, https://doi.org/10.5194/bg-8-883-2011, 2011.

Quast, C., Pruesse, E., Yilmaz, P., Gerken, J., Schweer, T., Yarza, P., Peplies, J., and Glöckner, F. O.: The SILVA ribosomal RNA gene database project: Improved data processing and web-based tools, Nucleic Acids Res., 41, 590-596, https://doi.org/10.1093/nar/gks1219, 2013.

R Core Team: R: A language and environment for statistical computing, R Foundation for Statistical Computing, Vienne, Austria, 2014.

Reddaway, J. M. and Bigg, G. R.: Climatic change over the Mediterranean Sea and links to the more general atmospheric circulation, Int. J. Climatol., 16, 651-661, 1996.

Schneider, C. A., Rasband, W. S., and Eliceiri, K. W.: NIH Image to ImageJ: 25 years of image analysis, Nat. Methods, 9, 671-675, https://doi.org/10.1038/nmeth.2089, 2012.

Sellegri, K., Nicosia, A., Freney, E., Uitz, J., Thyssen, M., Grégori, G., Engel, A., Zäncker, B., Haëntjens, N., Mas, S., Picard, D., Saint-Macary, A., Peltola, M., Rose, C., Trueblood, J., Lefevre, D., D'Anna, B., Desboeuf, K., Meskhidze, N., Guieu, C., and Law, C. S.: Surface ocean microbiota determine cloud precursors, Sci. Rep.-UK, 11, 281, https://doi.org/10.1038/s41598-020-78097-5, 2021.

Sun, C.-C., Sperling, M., and Engel, A.: Effect of wind speed on the size distribution of gel particles in the sea surface microlayer: insights from a wind-wave channel experiment, Biogeosciences, 15, 3577-3589, https://doi.org/10.5194/bg-15-3577-2018, 2018.

Tanhua, T., Hainbucher, D., Schroeder, K., Cardin, V., Álvarez, M., and Civitarese, G.: The Mediterranean Sea system: a review and an introduction to the special issue, Ocean Sci., 9, 789-803, https://doi.org/10.5194/os-9-789-2013, 2013.
Taylor, J. D. and Cunliffe, M.: High-throughput sequencing reveals neustonic and planktonic microbial eukaryote diversity in coastal waters, J. Phycol., 50, 960-965, https://doi.org/10.1111/jpy.12228, 2014.

Tovar-Sánchez, A., Rodríguez-Romero, A., Engel, A., Zäncker, B., Fu, F., Marañón, E., Pérez-Lorenzo, M., Bressac, M., Wagener, T., Triquet, S., Siour, G., Desboeufs, K., and Guieu, C.: Characterizing the surface microlayer in the Mediterranean Sea: trace metal concentrations and microbial plankton abundance, Biogeosciences, 17, 2349-2364, https://doi.org/10.5194/bg-172349-2020, 2020.

Trueblood, J. V., Nicosia, A., Engel, A., Zäncker, B., Rinaldi, M., Freney, E., Thyssen, M., Obernosterer, I., Dinasquet, J., Belosi, F., Tovar-Sánchez, A., Rodriguez-Romero, A., Santachiara, G., Guieu, C., and Sellegri, K.: A Two-Component Parameterization of Marine Ice Nucleating Particles Based on Seawater Biology and Sea Spray Aerosol Measurements in the Mediterranean Sea, Atmos. Chem. Phys. Discuss. [preprint], https://doi.org/10.5194/acp-2020-487, in review, 2020.

Upstill-Goddard, R. C., Frost, T., Henry, G. R., Franklin, M., Murrell, J. C., and Owens, N. J. P.: Bacterioneuston control of air-water methane exchange determined with a laboratory gas exchange tank, Global Biogeochem. Cy., 17, 1108, https://doi.org/10.1029/2003GB002043, 2003.

Verdugo, P., Alldredge, A. L., Azam, F., Kirchman, D. L., Passow, U., and Santschi, P. H.: The oceanic gel phase: A bridge in the DOM-POM continuum, Mar. Chem., 92, 67-85, https://doi.org/10.1029/2002GL016046, 2004.

Wietz, M., Wemheuer, B., Simon, H., Giebel, H. A., Seibt, M. A., Daniel, R., Brinkhoff, T., and Simon, M.: Bacterial community dynamics during polysaccharide degradation at contrasting sites in the Southern and Atlantic Oceans, Environ. Microbiol., 17, 3822-3831, https://doi.org/10.1111/1462-2920.12842, 2015.

Wikner, J. and Hagstrom, A.: Evidence for a tightly coupled nanoplanktonic predator-prey link regulating the bacterivores in the marine environment, Mar. Ecol. Prog. Ser., 50, 137-145, https://doi.org/10.3354/meps050137, 1988.

World Health Organization: The sea-surface microlayer and its role in global change, WMO, Geneva, 1995.

Wurl, O. and Holmes, M.: The gelatinous nature of the sea-surface microlayer, Mar. Chem., 110, 89-97, https://doi.org/10.1016/j.marchem.2008.02.009, 2008.

Wurl, O., Miller, L., Röttgers, R., and Vagle, S.: The distribution and fate of surface-active substances in the seasurface microlayer and water column, Mar. Chem., 115, 1-9, https://doi.org/10.1016/j.marchem.2009.04.007, 2009.

Zäncker, B., Bracher, A., Röttgers, R., and Engel, A.: Variations of the Organic Matter Composition in the Sea Surface Microlayer: A Comparison between Open Ocean, Coastal, and Upwelling Sites Off the Peruvian Coast, Front. Microbiol., 8, 1-17, https://doi.org/10.3389/fmicb.2017.02369, 2017.

Zhang, Z., Liu, L., Liu, C., and Cai, W.: Studies on the sea surface microlayer: II. The layer of sudden change of physical and chemical properties, J. Colloid Interf. Sci., 264, 148-159, https://doi.org/10.1016/S0021-9797(03)00390-4, 2003.

Zhou, J., Bruns, M. A., and Tiedje, J. M.: DNA recovery from soils of diverse composition, Appl. Environ. Microb., 62, 316-322, 1996. 